\title{
Understanding Behavior of Consumption Expenditure of Households
}

\author{
Syazwani Binti Mohd Bakri ${ }^{\mathrm{a}}$, Norimah Binti Rambeli @ Ramli ${ }^{\mathrm{b}}$, Emilda Binti Hashim $^{\mathrm{c}}$, \\ Maryam Mahdinezhad ${ }^{\mathrm{d}} \&$ Norasibah Binti Abdul Jalil ${ }^{\mathrm{e}}$ \\ ${ }^{a}$ Faculty of Management and Economics, UPSI, Malaysia, syazwanibakrirokiah@yahoo.com \\ ${ }^{b}$ Faculty of Management and Economics, UPSI, Malaysia, norimah@fpe.upsi.edu.my \\ ${ }^{c}$ Faculty of Management and Economics, UPSI, Malaysia, emilda@fpe.upsi.edu.my \\ ${ }^{d}$ Faculty of Management and Economics, UPSI, Malaysia, maryam.m@fpe.upsi.edu.my \\ ${ }^{e}$ Faculty of Management and Economics, UPSI, Malaysia, norasibah@fpe.upsi.edu.my
}

\begin{abstract}
There are two major trends in household financial level in Malaysia. The financial size level of households has expanded since 2002 so as the composition of household assets now are more wide-ranging. A study is carried out to identify the dominant factors that influence the household consumption expenditure in Malaysia between year 1970 to 2014. This study uses household income (YH) and inflation (CPI) as its independent variables, while using household consumption expenditure (C) as its the dependent variable. This study employs econometric method, namely Ordinary least squares (OLS) or linear least squares to determine variables that are significant and accurate. The result of this research shows that all tested variables influence household consumption expenditure in Malaysia. The result also suggests that, household income has positive and significant relationship with household consumption expenditure. Meanwhile, consumer price index, which represents inflation rate, negatively influences household consumption expenditure. To emphasize, Multiple Linear Regression model is the best model to estimate household consumption spending pattern in Malaysia.
\end{abstract}

\section{Keywords:}

Consumption spending; inflation, household income

\section{INTRODUCTION}

Consumer behavior is any individual action in relation to the use of materials and services, including economic decision-making processes that determine the behavior (Block and Roering, 1979). According to Goldsmith (1996), household consumption expenditure pattern changes in line with the changing in times. In order to meet the necessary expenses, money or income shall be dealt with as soon as possible. This is because the change in time has become one of the factors that influence the pattern of household consumption indirectly, as the change currently affects the cost to acquire goods and services, due to inflation that prevails in a country.

Planning household expenditure is vital to meet the needs of purchasing for goods or services that are available in the market. Thus, the goal of every household is to fulfill his or her basic needs such as food, clothing, shelter, vehicles, transportation and education. The 
size of households' financial level has improved significantly in recent years, as reflected in the increase in households' assets and liabilities. The composition of the financial standing in households has also changed, with higher holdings of financial assets and properties. There are two major trends in the households' financial level in Malaysia. First, the financial level of households has grown in size since 2002 and second, the composition of household assets are now more diverse (BNM Annual Report, 2013). Private consumption has increasingly become an important component in Malaysian economy. It has driven economic growth over the last decade, which increased at an average annual rate of $7.4 \%$ for the period 2000 to 2009 (Annual Report 2010).

Todaro and Smith (2015) define development as a process that views of various dimensions, involving the establishment and adjustment of economic and social system. A country will not develop well should the economic situation is not stable, such as during economic and financial crises. According to Malaysia Plan, rising cost of living is a major issue faced by households. The average monthly household expenditure increased by $10.1 \%$ per annum from RM1,248 in 2009 to RM2,0155 in 2014. Furthermore, the high levels of indebtedness among households also affect their financial situation because of their tendency to make personal loans in order to cover daily expenses. It is difficult to identify the factors that affect consumption or factors that are most reacted to consumption expenditure of the households sector. This is due to the consumption expenditure of the households sector, which is influenced by various factors, either direct factor as disposable income, or indirect factors, such as the increase in the aggregate price of a goods and services. Sometimes, the estimation model built is in conflict with existing economic theories causing difficulties to build a suitable estimation model in real economic situation. Thus, estimation of consumption model can be used to identify factors considering the occurrence of economic problems as well as identify measures to overcome the economic problems associated with the household sector.

The financial crises that occurred in 1997 and 2008 have had major impact on Malaysian economy, which also have affected the household sector. It is difficult to identify the impact of variables and economic policies taken by the government in order to tackle the financial crisis that influence the patterns of household consumption expenditure. Therefore, the change in household consumption expenditure in Malaysia is important to determine the best multiple linear regression model for budgeting purposes. Moreover, the identification of the most important factors that had influenced household consumption expenditure in Malaysia between 1970 and 2014 was important to get an overview of the economic situation of households.

\section{LITERATURE REVIEW}

Fereidouni and Tajaddini (2017) do a study on consumption expenditure by using quarterly data from 1978 to 2012 in the U.S. This study uses the fully modified ordinary least squares (FMOLS) estimation method developed by Phillips and Hansen (1990). The results of the study show that wealth has a positive impact on household consumption expenditure. Its wealth depends on earnings earned monthly as well as other sources of income such as investment. This suggests that high income households will make huge consumption expenditure each month. 
Similarly, studies in China conducted by Chen, Guo, and Zhang (2010) on the effects of wealth on consumption spending of the people in China. This study uses a vector error correction model on national quarterly data of China. The findings reveal that there is a longterm relationship between disposable income and consumption expenditure. In addition, revenue and assets increase consumption in China, with revenue being the largest contributor to the increase in consumption in China. The result is consistent with the old study done by Nuriz et. al. (1985). They find that socio-economic factors, namely, income, education and place of residence of households, play important role in consumer household expenditure. Income is found to be the main factor that influence household consumption expenditure for the financial resources of households is earned income. Rising in household income lead to rising in household spending on goods and services, as well.

De Bonis and Silvestrini (2012) indicate in their study that household financial and wealth factors influence consumption in 11 organizations for Economic Co-operation and Development (OECD) countries using quarterly data from 1997 to 2008. Based on the unit root test results, revenue and the CPI positively affect household consumption expenditure in OECD countries. The results of their study are consistent with the research findings by Chen, et. al. (2010) whereby income is the most dominant factor in affecting household consumption expenditure compared to CPI or inflation. By using cross-sectional data in 300 cities in the United States, Taylor (2010) does his study on price elasticity and income in determining consumption expenditure. Based on the simple double-logarithmic demand functions, he discovers that the price of the item positively affects consumption expenditure. It means the increase in prices of goods lead to an increase in household consumption expenditure. The point being, the increase in consumption expenditure is not because of an increase in the quantity of consumption, but due to the relative increase in prices of goods. The above studies confirmed previous findings by Mohd Nor (1981) on the welfare of the household government survey in 1978 of 10,000 households across the country. The result showed that $25 \%$ of respondents found that their living standards were the same or have decreased compared to five years ago.

Meanwhile, Zhang and Wan (2004) demonstrate that, by giving loans to households for the purchase of goods as done by banks in China, resulted in households increasingly subject to liquidity constraints. In addition, the growing income inequality in China demonstrates further reduction in households spending due to falling in average income. Such condition leads to decline in household consumption expenditure while boost the savings rate in China. Hence, the economic reform leads to major changes in the behavior of household consumption, in which liquidity constraints affect household consumption expenditure. According to Joseph and Aloysius (1987), the evidence is weak against RE-lifecycle model analysis of the relationship between changes in consumption and the past can determine the change in income. Liquidity constraints, however, do not show much evidence against the assumption of perfect capital markets.

Du and Wang (2017) use CULS data in China in their study of household consumption expenditure. The outcome of their studies reveals that income positively affects consumption expenditure for high-income groups in China. The elasticity value between 0.33 and 0.38 , indicates the growth in income for the entire household in the City greatly influence the increase in consumption spending in China. In contrast to the study, Mok et. al. (2011) show different results among the character differences in consumers. Obtaining data from the Household Expenditure Survey 2004-2005 in Malaysia, the results of the Weighted Ordinary ISSN 19852126 
Least Square (WOLS) disclose that there are character differences between some groups according to the level of household spending. Households comprising of the lowest household expenditure groups spend the most of their income $(39 \%)$ on food, while the highest household spending groups consume $28 \%$ of their income on vehicles.

In general, there is a relationship between income and expenditure on consumption based on macroeconomic studies conducted by Diacon and Maha (2015) conducts macroeconomic study on income, consumption and GDP in 97 countries using time series and cross-sectional data. They divide those countries into three categories, high-income, middle-income and lowest-income nations. Income levels have greater impact on households consumption spending in low and high income countries. On the contrary, there is a weak relationship between income and consumption expenditure among people in middle income countries. Households of lower income countries, in fact, will allocate their income to purchase basic needs. In contrast, households from high-income countries have many sources of income whereby their investment will increase along with their consumption expenditure. $\mathrm{Li}$ and Gan (2016) in their credit constraints study on household consumption expenditure in China using information from the Life Cycle Theory of Modigliani and Permanent Income Hypothesis of Friedman. They validate that household consumption expenditure in China is influenced by income, family size, health status and credit constraints.

Varlamova and Larionova (2015) examine macroeconomic and demographic determinants of household consumption expenditure in OECD countries using time series data. Based on household dynamics analysis, disposable income, inflation, government spending, interest rates, populations and education levels affect household consumption expenditure. Most household consumption expenditure is influenced by price and related factors such as tax, income and import levels. Income levels affect spending on consumption significantly. In another study, Goldberg (2017) discovers that income-sharing is low among farmers in Malawi during windfall income. However, the consumption expenditure of these groups will increase dramatically in order to avoid sharing obligations. Although both studies differ in terms of data, location and methodology, both studies have the same meaning that household consumption expenditure is heavily influenced by income. On the other hand, Huy (2012) relates consumption expenditure with human capital stock, such as work experience, education and training, using Tobit analysis. Those with good human capital stock will spend more on their children's education. Households with higher education and income, tend to allocate higher spending on education for their children.

\section{HYPOTHESES}

The general hypotheses used in this study are as follows:

a. The annual household average income affecting household consumption expenditure

$\mathrm{H}_{0}$ : The annual household average income is important in influencing the household consumption expenditure in Malaysia between 1970 and 2014.

$\mathrm{H}_{1}$ : The annual household average income is not important in influencing the household consumption expenditure in Malaysia between 1970 and 2014. 
b. The Consumer Price Index affecting household consumption expenditure

$\mathrm{H}_{0}$ : The Consumer Price Index is important in influencing the household consumption expenditure in Malaysia between 1970 and 2014.

$\mathrm{H}_{1}$ : The Consumer Price Index is not important in influencing the household consumption expenditure in Malaysia between 1970 and 2014.

\section{METHODOLOGY AND MODEL SPECIFICATIONS}

$\mathrm{Xu}$ (2015) mentions that there are several factors that influence the behavior of household consumption expenditure, particularly, household income and inflation as represented by the consumer price index (CPI), in Malaysia. Thus, both factors are the independent variables that affect household consumption expenditure, the dependent variable, in Malaysia between 1970 and 2014. The model specification is as follows;

Model specifications:

$$
C_{t}=\beta_{0}+\beta_{1} Y H_{t}+\beta_{2} C P I_{t}+\varepsilon_{t}
$$

Where:

$\mathrm{C}_{\mathrm{t}} \quad=$ Consumption of Household in year $\mathrm{t}$

$\mathrm{YH}_{\mathrm{t}} \quad=$ Annual Households Average Income in year $\mathrm{t}$

$\mathrm{CPI}_{\mathrm{t}}=$ Consumer Price Index base year 2010 in year $\mathrm{t}$

$\mathrm{t} \quad=$ annual data from 1970 to 2014

$\varepsilon_{\mathrm{t}} \quad=$ Terms of errors

According to the Department of Statistics, household consumption expenditure is the expenditure for private consumption on goods and services during the reference period. This includes all expenses in cash or credit by members of households on goods and services for personal use (including taxes paid for goods and services). In addition, all goods, services and facilities received in kind, either free or concession. Household income (IR) is recognized as a total household income in the form of cash and / or kind which are of a recurring nature and typically, accrue to the household or household members over a period of a year (Economic Planning Unit, 2015). Data on household income is collected through the Household Income Survey (HIS). Whereas, the Consumer Price Index (CPI), which is based on the Laspeyres formula, which measures the average change in prices of the basket of goods and services specified, represents the households expenditure pattern in Malaysia with 2000 as the base year. It is a composite index based on weighted by regional expenditure of three regional indices computed separately for Peninsular Malaysia, Sabah and Sarawak are collected separately (Bank Negara Malaysia, 2016).

\section{FINDINGS}

The finding will be discussed in three criterias; namely economics, statistics and econometrics. Below is the estimation result below as in equation (2); 


$$
\begin{array}{ll}
\widehat{C}_{t}=17.118+0.986 Y \hat{H}_{t}-0.292 C \widehat{P} I_{t} \\
S e=(0.411)(0.230) & (0.237) \\
\mathrm{t}=(41.669)(4.291)^{* *} & (-1.233)^{*} \\
& \\
R^{2} & =0.860 \\
F^{*} & =129.365 \\
\text { Durbin-Watson } & =0.356 \\
\mathrm{~N} & =45
\end{array}
$$

Where;

$C_{\mathrm{t}} \quad=$ Consumption of Household at year $\mathrm{t}$

$\mathrm{YH}_{\mathrm{t}}=$ Annual Income Households Average in year $\mathrm{t}$

$\mathrm{CPI}_{\mathrm{t}}=$ Consumer Price Index base year 2010 in year $\mathrm{t}$

$\mathrm{t}=$ annual data from 1970 to 2014

$\varepsilon_{\mathrm{t}} \quad=$ Error terms

While the significant level analyses are as follows;

$* *=$ Significant at the $99 \%$ confidence level

$*$ = Significant at $75 \%$ confidence level

Note: All data in Natural Logarithma

\section{Economic criteria}

From table 1, 1\% increase in household income (YH) causes an increase of $0.006 \%$ household consumption expenditure (C). Similarly, the elasticity of the consumer price index (CPI) is inelastic. Each $1 \%$ increase in the consumer price index (CPI) decreased by $0.001 \%$ of household consumption expenditure (C). Notation for household income is positive and in line with Keynesian theory. This shows that any increase in household income by $1 \%$ led to an increase in household consumption expenditure in Malaysia by $0.986 \%$. While the independent variables of the consumer price index is negative, which is in line with the theory of demand. That means any increase in the consumer price index by $1 \%$ causes household consumption expenditure in Malaysia to decrease by $0.292 \%$ and vice versa.

Table 1: Elasticity and notation

\begin{tabular}{lcc}
\hline INDEPENDENT VARIABLES & \multicolumn{1}{c}{ MODEL BUDGETING } \\
\hline HOUSEHOLD INCOME (YH) & $\widehat{C}_{t}=17.118+0.986 Y \hat{H}_{t}-0.292 C \hat{P} I_{t}$ \\
CONSUMER PRICE INDEX (CPI) & 0.006 & NOTATION \\
\hline
\end{tabular}




\section{Criteria statistics}

Based on the value of $\mathrm{R}^{2}$ in the first estimation model, as much as $86 \%$ of the dependent variable, namely household consumption, can be explained by the independent variable of household income and CPI. Meanwhile, the standard deviation for each parameter for household income is 0.230 and the consumer price index is 0.237 . From the above result, the value of $F(0.05,2,42)$ was 3.23 while the value of the test statistic $F^{*}$ is 129,365 . Therefore, due to the $\mathrm{F} *>\mathrm{F}(\alpha, \mathrm{V} 1, \mathrm{~V} 2)$, this model is good and there is sufficient evidence to reject the null hypothesis (Ho) at the $95 \%$ confidence level. The test results of significance for individuals (T-test) for household income shows that $t^{*}$ is 4,291 while the value $t$ is 2.021 . This illustrates that $\mathrm{t} *>\mathrm{t}(\alpha, \mathrm{nk})$, thus, we reject Ho which means household income is important in explaining the consumption expenditure of households at $99 \%$ confidence level. For the consumer price index, $\mathrm{t}^{*}$ is -1.233 which is smaller than the value of $2,021 \mathrm{t}(\mathrm{t} *<\mathrm{t}(\alpha$, nk) which means we accept Ho. This means that the consumer price index variables are not significant in explaining consumption expenditure of households at $75 \%$ confidence level.

\section{Criteria econometrics}

(Tests of identifying problems of autocorrelation, heteroscedasticity and multicollinearity).

The issue of autocorrelation can be identified by the Durbin Watson and Run test, while for heteroscedasticity problem can be identified through Part and Glejser test. Meanwhile, the problem of multicollinearity can be identified through Pearson correlation test.

Table 2: The test results of autocorrelation, heterocedasticity and multicollinearity.

\begin{tabular}{|c|c|c|}
\hline TEST & RESULTS & HYPOTHESIS \\
\hline \multirow[t]{3}{*}{ DURBIN WATSON } & $\mathrm{DW}=0356$ & \\
\hline & $\begin{array}{l}\text { 1\% SIGNIFICANCE LEVEL: NEGATIVE } \\
\text { AUTOCORRELATION }\end{array}$ & - \\
\hline & $\begin{array}{l}\text { 5\% SIGNIFICANCE LEVEL: NEGATIVE } \\
\text { AUTOCORRELATION }\end{array}$ & \\
\hline RUN TEST & $\mathrm{K}=9(24.0667,22.9111)$ & REJECT $\mathrm{H}_{0}$ \\
\hline \multirow[t]{2}{*}{ PART TEST } & $\ln \widehat{u}=-0.121+0.074 Y \hat{H}_{t}-0.07 C \widehat{P} I_{t}$ & ACCEPT $\mathrm{H}_{0}$ \\
\hline & $\mathrm{F} *(1,695)<\mathrm{F} 0.05,2,42(3.23)$ & \\
\hline \multirow[t]{2}{*}{ GLEJSER TEST } & $|\hat{u}|=-0.405+0.268 Y \hat{H}_{t}-0.252 C \widehat{P} I_{t}$ & $\mathrm{ACCEPT} \mathrm{H}_{0}$ \\
\hline & $\mathrm{F}^{*}(2,160)<\mathrm{F} 0.05,2,42(3.23)$ & \\
\hline PEARSON & $\mathrm{R}^{2}(0.860)<\mathrm{CORR}(\mathrm{YH}, \mathrm{CPI})=0.981$ & - \\
\hline
\end{tabular}


Based on table 2, The estimation model shows negative autocorrelation at the level of significance of $1 \%$ and 5\%, respectively. Despite that, part and Glejser tests show that the problem of heteroscedasticity does not exist. Other than that, there are serious multicollinearity or perfect multicollinearity occur based on Pearson correlation values. That is, the coefficient of determination $\left(\mathrm{R}^{2}\right)$ is smaller than the correlation between YH_7014 and CPI_7014 of 0.981 . Therefore, the solution can be done by removing one of the independent variables (either YH or CPI). However, some literatures also suggest to transform the initial model.

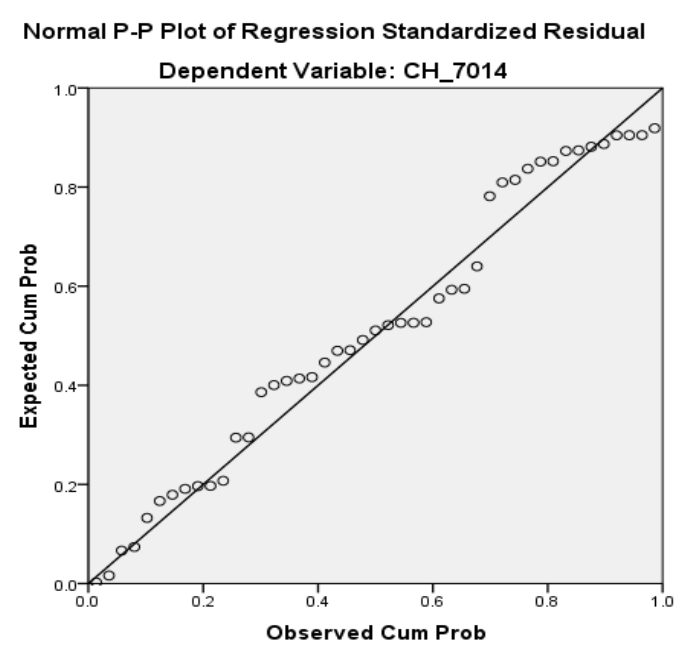

Figure 1: Normal PP Plot

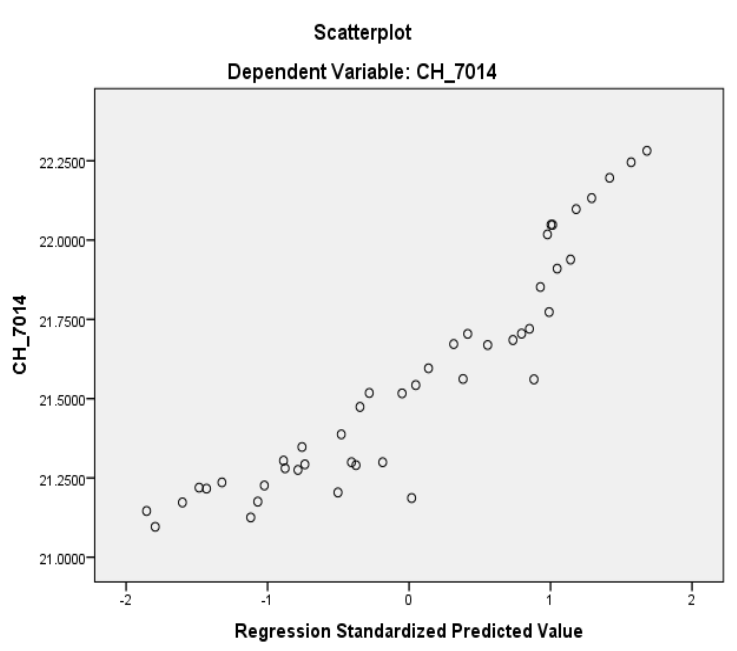

Figure 2: Scatterplot

Based on figures 1 and 2 above, we can conclude that the relationship between the dependent variable, namely household consumption expenditure, and the independent variables, household income and consumer price index, are very close because the figures are almost unlined and went straight line.

\section{DISCUSSIONS AND RECOMMENDATIONS}

Based on the above analyses, the consumer price index is negatively related to household consumption spending. This result is consistent with previous study as conducted by Bhattacharya, Chatterjee (1971), which states that the factor affecting household consumption per capita is due to changes in the consumer price of an article in which the relationship is negative for both areas in India. It simply means that the rise in consumer prices causes reduction in household consumption. It can be the effect of higher cost in obtaining goods and services. Hence, any increase in consumption is not due to rising prices since the escalation in prices of goods and services lead to lower demand for those goods and services.

The result reveals that the other independent variable, that is, household income is positive and is in line with previous study as conducted by Kiran \& Navneet Sethia (2005). Both studies confirm that income is important in obtaining goods and services, especially with persistent growing costs in the world economy. Income can allow households to purchase goods, nutritious food, transportation, health care and so on. The dependence of income in household consumption makes income as a dominant factor to changes in 
household consumption. When income rise stablely, household consumption will increase. The reverse is also true whereby decline in revenue causes household consumption to fall sharply.

The findings are consistent with the built hypotheses. We mention earlier in the study that the main or predominant factors that are expected to affect household consumption expenditure in Malaysia are income and CPI (weak relationship). Due to perfect multicollinearity problem, we suggest that CPI to be discarded and replaced by some new variables for best result. Among the variables that can be used to replace the existing variables is the income level of affluence or wealth. Point being, according to BNM Annual Report (2010), the main factors to change household consumption expenditure is growing affluence among Malaysians, which is supported by a strong increase in disposable income and wealth accumulation. Moreover, demographic Malaysians can also be replaced with the original variables. This is due to the fact that large numbers of the working-age population are young people, who are capable to support growth in revenue. Young people, in general, have a tendency to use a higher marginal propensity to consume for non-essential goods and services. For future study, these factors may be an important factors to influence household consumption expenditure, thereby significantly improve the estimation model.

\section{CONCLUSION}

Based on the objective of the study, this multiple regression model, in which its independent variables, namely household income and inflation, is robust and able to explain the strong and significant household consumption expenditure. The most important factor that influences household consumption expenditure is the annual household income. Linear regression model constructed can be used as an overview of the socio-economic status of households in Malaysia.

\section{References}

Bhattacharya, N. \& Chatterjee, GS (1971). Consumer Prices and per Capita Household Consumption in

Rural India: Variation between States. Economic and Political Weekly 6 (44): 2249- 2253,

Block CE \& Roering, KJ (1979). Essentials of Consumer Behavior. Illinois: The Dryden Press.

Chen, J., et. al. (2010). How Important Are Wealth Effects on China's Consumer Spending? Chinese Economy, 43(2), 5-22.

De Bonis, R., \& Silvestrini, A. (2012). The Effects Of Financial And Real Wealth On Consumption: New

Evidence From OECD Countries. Applied Financial Economics, 22(5), 409-425.

Department of Statistics. Report on Household Expenditure Survey Malaysia. 2004/2005. Kuala Lumpur:

Department of Statistics. Downloaded from http://www.statistics.gov.my

Diacon, P. E., \& Maha, L. G. (2015). The Relationship between Income, Consumption and GDP: A Time

Series, Cross-Country Analysis. Procedia Economics and Finance, 23, 1535-1543.

Du, Y., \& Wang, M. (2017). Population Ageing, Domestic Consumption and Future. Rising China: Global Challenges and Opportunities 301.

Fereidouni, H. G., \& Tajaddini, R. (2017). Housing Wealth, Financial Wealth and Consumption

Expenditure: The Role of Consumer Confidence. The Journal of Real Estate Finance and Economics, 54(2), 216-236.

Mohd Nor Ghani (1981). Alternative Development Strategies. Development Seminar in the Eighties.

ISSN 19852126 
Selangor: Universiti Kebangsaan Malaysia.

Goldberg, J. (2017). The effect of social pressure on expenditures in Malawi. Journal of Economic Behavior \& Organization, 143, 173-185.

Goldsmith, E. (1996). Resource Management for Individuals and Families. (3 ${ }^{\text {rd }}$ ed.). St.Paul: Minnesota

West Publishing Company.

Guy Debelle. (2004). Household Debt and the Macroeconomy. BIS Quarterly Review, March 2004.

Huy, V.Q., 2012. Determinants of educational expenditure in Vietnam. International Journal Application

Economics 9 (1), 59-72.

Joseph G. Altonji \& Aloysius Siow. (1987). Testing The Response Of Consumption To Income Changes

With (Noisy) Panel Data. The Quarterly Journal ofEconomics,293-328.

Kiran M.O.R. \& Navneet Sethia. (2005). Factors that Influence Household and Individual Food Consumption: A Review of Research and Related Literature. Journal of Management 5 (2).

Li, C., Lin, L., \& Gan, C. E. (2016). China Credit Constraints And Rural Households' Consumption Expenditure. Finance Research Letters, 19, 158-164.

Masud, J. (1982). Spending Patterns and Management among Multiple Family Malays and Chinese in the

Federal Territory. Pertanika 5(1),45-52.

Mok, T. P., et. al. (2011). Household Size Economies: Malaysian Evidence. Economic Analysis and Policy, 41(2), 203-223.

Nuriz Yahya, et. al. (1985). Effect of Factors Socioeconomic on Consumer Awareness. Pertanika 8(1),89-97.

Phillips, P. C. B., \& Hansen, B. E. (1990). Statistical Inference In Instrumental Variable Regression With

I(I) Processes. Review of Economic Studies, 57(1), 99-125.

Taylor, L. D. (2010). Price and Income Elasticities Estimated from BLS Consumer Expenditure Surveys

and ACCRA Price Data: Some Preliminary Results. In Consumer Demand in the United States (pp. 107-126). Springer New York.

Todaro, M.P. and Smith, S.C. (2015). Economic Development, 12th Editions. London: Pearson.

Varlamova, J., \& Larionova, N. (2015). Macroeconomic And Demographic Determinants Of Household

Expenditures In OECD Countries. Procedia Economics and Finance, 24, 727-733.

$\mathrm{Xu}, \mathrm{J}$. (2015). Understanding the Household Consumption Behavior in Urban China. The Singapore Economic Review, 1550062 (21 pages).

Zhang, Y and Wan, G.H. (2004). Liquidity Constraint, Uncertainty and Household Consumption in China. Applied Economics, 36, 2221-2229. 